Chapter 32

HISTORY OF COLUMBIA RIVER JETTIES

\author{
R. E. Hickson and F. W. Rodolf \\ Portland District, Corps of Engineers \\ Department of the Army \\ Portland, Oregon
}

\title{
INTRODUCTION
}

Columbia River is the largest river on the Pacific coast of the United States. It heads at Columbia Lake in British Columbia, about 80 miles north of the international boundary, and flows northward parallel to the summit of the Rocky Mountains for about $185 \mathrm{mlles}$, thence turns back and flows generally southward through Upper and Lower Arrow Lakes and enters the United States about 25 miles west of the northeast corner of the state of Washington. Thence the river flows by a sinuous course southward, westward, and southeastward to the oregon-Washington boundary, thence generally westward between the two states, discharging into the Pacific Ocean 583 statute miles north of San Francisco Bay and 154 miles south of the Straits of Juan de Fuca (distances computed from differences in latitude). The river has a total length of 1,210 miles, of which 750 miles are in the United States.

The river and 1ts tributaries drain parts of seven states and a large part of British Columbia. The southern limit of its basin is in Nevada, and its eastern boundary is the Continental Divide; the area of the drainage being about 259,000 square miles, of which about 220,000 are in the United States. The watershed is generally rugged and precipitous, although many benches, flats, and valleys exist throughout the basin. The main tributaries are the okanogan, Kootenai, Clark Fork, Snake, and Willamette Rivers. of these, the Snake, which drains an area of 109,000 square miles, is by far the largest.

The extreme low water flow of Columbia River at its mouth, exclusive of tide water, is estimated at $65,000 \mathrm{sec} .-\mathrm{ft}$, while the maximum discharge of record, during the flood of June 1894, was about 1,200,000 sec.-ft. Maximum discharges, due to melting snows in the high headwaters, occur during the period from May to July and the average freshet flow is about 660,000 sec.-ft.

Low flow generally occurs during November through February; the average low flow being about 70,000 sec.-ft. During the period of low flow, winter freshets occur, due principaliy to flood conditions in the tributaries west of the Cascade Range, and, occaslonally, the winter freshets on the lower river exceed the average summer freshet.

The Columbla River is not classed as a sediment-bearing stream and for the greater part of the year the river is clear, but during freshets a small amount of material is carried in suspension. Measurements made below the mouth of the willamette Rlver in 1922 showed about 120 parts per militon in suspension during average freshet stage. This, however, does not include the bed load of coarser sand, which, during the summer freshets, travels down the river bed in waves of material that range from $8 \mathrm{ft}$. to 14 or more $\mathrm{ft}$. In height near the mouth of iflamette River but decrease in height as they travel down the channel. This bed load is the source of material forming the shoals in the lower river. Some of the sand finally and progressively reaches the ocean and is undoubtedly the major source of the beach sands extending on each side of the river's mouth.

Tides at the mouth of Columbia River have the diurnal inequality typical of the Pacific Coast of the United States with a long runout to lower-low normally following higher-high water. The mean range of tide is $6.5 \mathrm{ft}$; the range from mean-lower-low water to mean higher-high water is $8.5 \mathrm{ft}$; and extreme tides range from minus $2.5 \mathrm{ft}$. to plus $11.5 \mathrm{ft}$. Tidal effect extends upriver $145 \mathrm{miles}$ to Bonneville Dam during perlods of low-river flow. River discharge and tidal flow must be considered together as they are united in their action. The ebb discharge at the entrance averages about 1,350,000 sec.-ft., while the peak flow recorded 
during the freshet of 1933 was $3,065,000 \mathrm{sec} .-\mathrm{ft}$. Data regarding flow at the mouth of the river, taken from the current survey of 1933, are shown in the following table:

TABLE I

\begin{tabular}{l|c|c|c|c|c|c}
\hline \multirow{2}{*}{ Month } & $\begin{array}{c}\text { Number } \\
\text { of } \\
\text { tidal } \\
\text { cycles }\end{array}$ & \multicolumn{2}{|c|}{$\begin{array}{c}\text { Average river } \\
\text { discharge in } \\
1,000 \text { sec.-ft. }\end{array}$} & $\begin{array}{c}\text { Average dura- } \\
\text { tion of tides } \\
\text { in hours }\end{array}$ & \multicolumn{2}{|c}{$\begin{array}{c}\text { Average tidal } \\
\text { flow In I,000 } \\
\text { sec. -ft. }\end{array}$} \\
\cline { 4 - 7 } & 8 & Flood & Ebb & Flood & Ebb \\
\hline April & 13 & 315 & 5.43 & 6.90 & 1,037 & 1,345 \\
May & 7 & 556 & 4.95 & 7.55 & 971 & $1,481 *$ \\
September & 125 & 5.81 & 6.44 & 1,257 & 1,306 \\
\hline
\end{tabular}

*Maximum ebb discharge during this period was $3,065,000$ sec.-ft.

MOUTH OF COLUMBIA RIVER BEFORE IMPROVEMENT

The mouth of Columbia River lies between a low sand spit, Point Adams, on the south, and a high, rocky headland, Cape Disappointment, on the north. Before construction of the south jetty, a sand beach extended southward 18 miles from Polnt Adams to Tlilamook Head, the headland next south of the entrance. Extending north and west from Point Adams were numerous and changeable shoals known as Clatsop Spit.

Cape Disappointment, about 6 miles north-northwest from Point Adams, is the only headland on the low sand beach that extends northward from Tillamook Head to

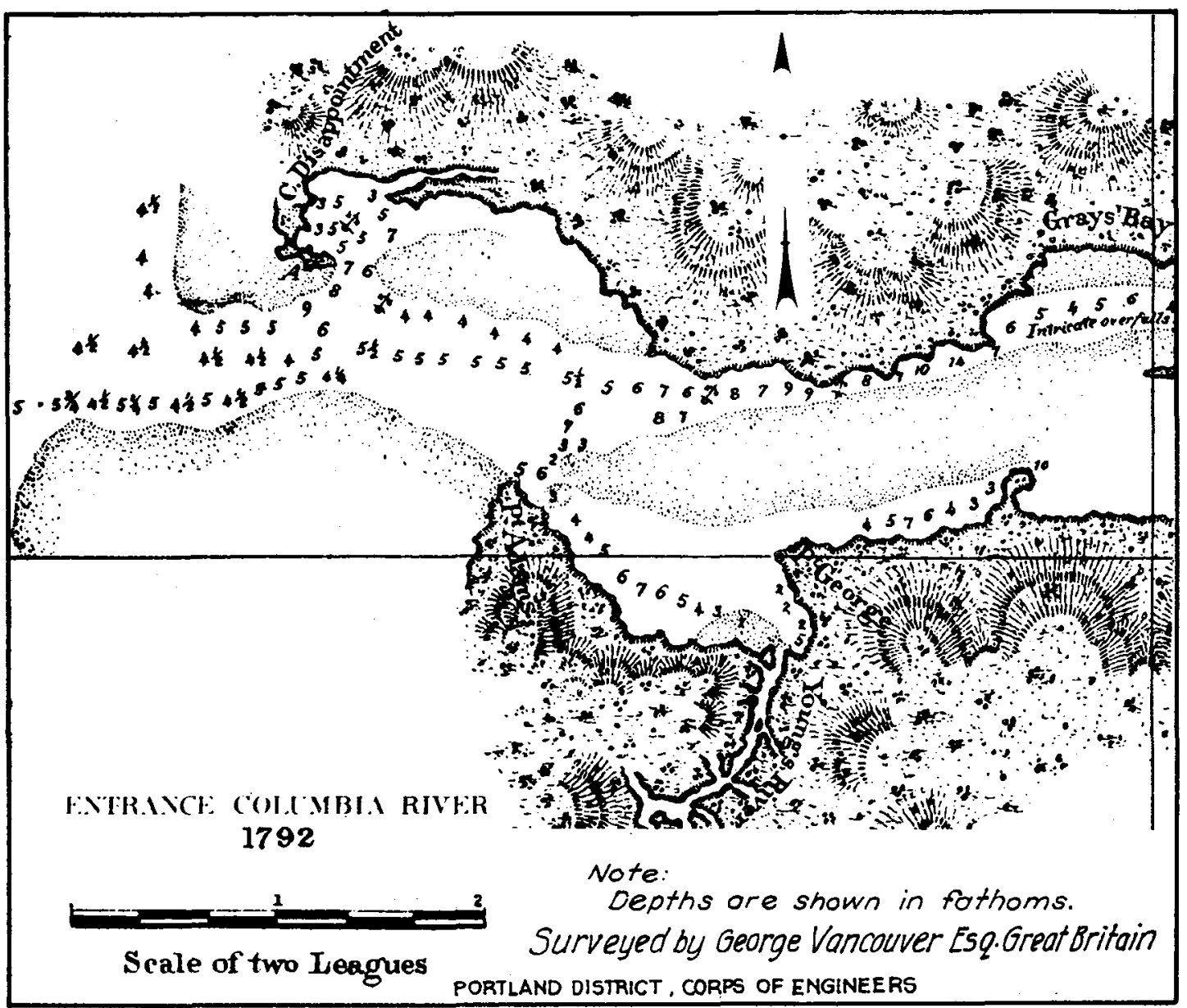

Fig. I 


\section{HISTORY OF COLUMBIA RIVER JETTIES}

Point Greenville, a distance of about 94 miles. The cape is the southern end of a coast range spur that swings in a curve, concave eastward, to form the west shore of Bakex Bay, and consists of rounding hills covering an area about 3 miles long by 1 mile wlde. The seaward faces of the hills are precipitous cliffs, with the extreme southern point, formerly called Cape Hancock but now called Cape Disappointment, rising about $190 \mathrm{ft}$. above the river; and North Head, the extreme western point, rising about $175 \mathrm{ft}$. above the ocean. The shoal area about the southern end of the cape is called Peacock Spit. The ocean bar connects Peacock Spit to Clatsop Splt by a curve, convex seaward, across the river entrance with 1 ts yertex, varying in location from year to year, and, before construction of the jetties, ranged from $2-1 / 2$ to $4-1 / 2$ mlles west of a line connecting Cape Disappointment with Point Adams.

The earliest known chart of Columbia River at the mouth is a sketch made by Admiral Vancouver in 1792, shown in Fig. 1. The next known survey was made by $\mathrm{S} 1 \mathrm{r}$ Edward Belcher in 1839, show in Fig. 2. Condition of the river entrance in 1885, before construction was started on the south jetty, is shown in Fig. 3 . The shoals, bars, and beaches at the river entrance are composed of a sand that is readily shifted in location by wave action, currents, and wind. Before construction of the jetties, both Clatsop spit and Peacock Spit were constantly changing in position and depth. Inspection of Figs. 1, 2, and 3, shows that the direction of Clatsop Spit had varied from westward, with a length of nearly 8 miles in 1792 , to northwestward, with a length of 3-1/2 miles in 1885. In 1839 1ts northern edge was but $1 / 2$ mile north of Point Adams, while in 1885 it was $2-1 / 2$ miles. The

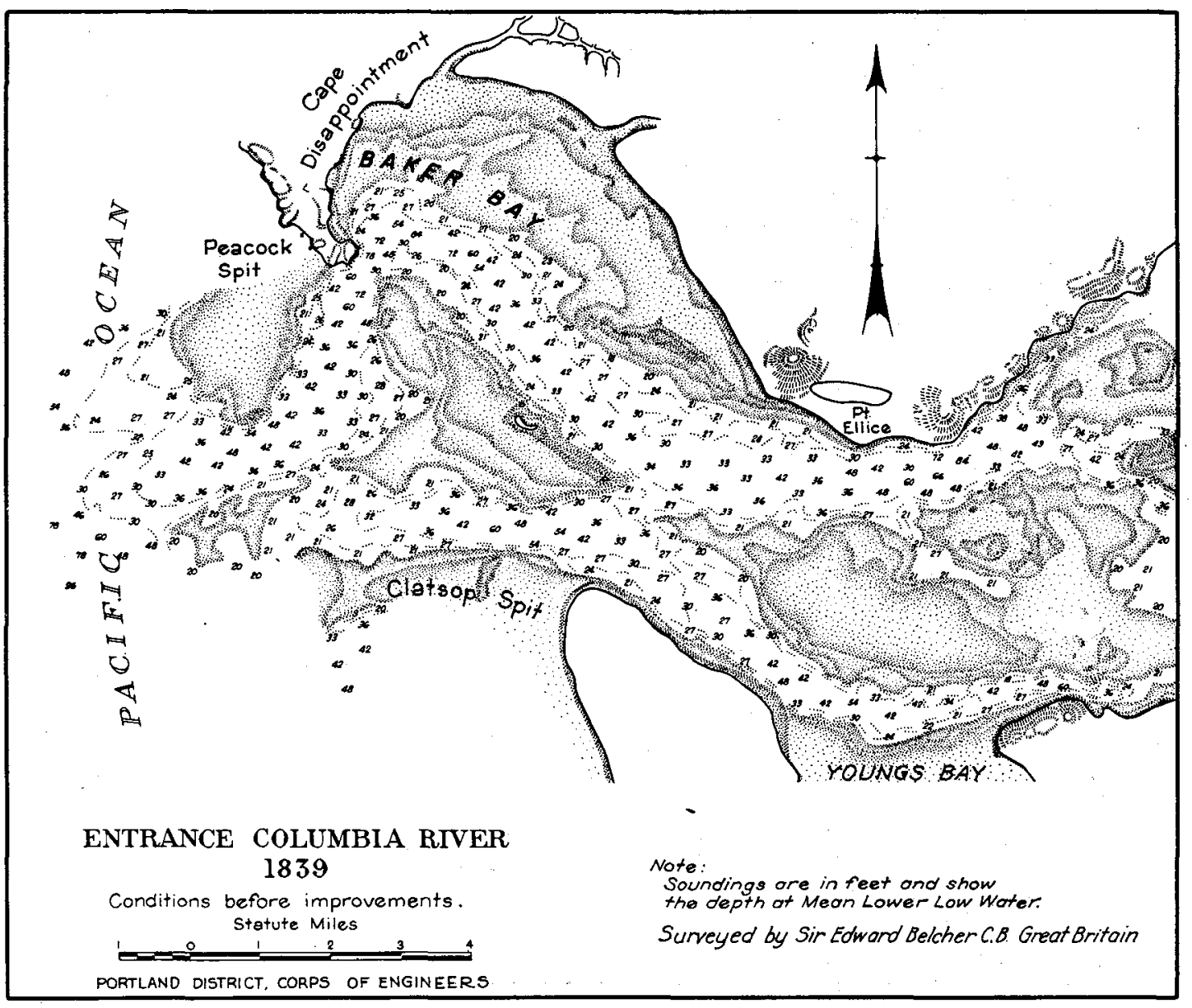

Fig. 2 


\section{COASTAL ENGINEERING}

channel side of Peacock Spit varied in direction from south to west, and its southerly limit ranged between $3 / 4$ and 2-1/2 miles south of Cape Disappointment.

The steep offshore slope along the Pacific coast in this area, combined with high wind velocities, results in heavy wave action which renders beach erosion and hydrographic studies difficult. The effect of the many forces and the resultant sand movements have been investigated and discussed in numerous reports, the most comprehensive of which are the following:

1903 report. The report of a board of engineers contained in the Annual Report of the War Department, 1903, Chief of Engineers, part 3, includes a series of charts showing changes at the mouth of the river up to that time, and analyzes the sand movement.

Current Survey, 1932-1933. A report by R. E. Hickson of the District Eng1neer's office gives the results of extensive current measurements and contains information on sand sizes, tidal flows, suspended load, and other general data.

Hodge report. A report on the mechanical and petrographic characteristics of the material forming the estuary and ocean beach, and gives consideration to the movement and sorting of beach sands by winds.

Technical Memorandum No. 20, December 24, 1936. Th1s report, made by the U.S. Tidal Model Laboratory, Berkeley, California, covers studies made to determine the cause of recession of the shore of Clatsop Spit immediately south of the south jetty.

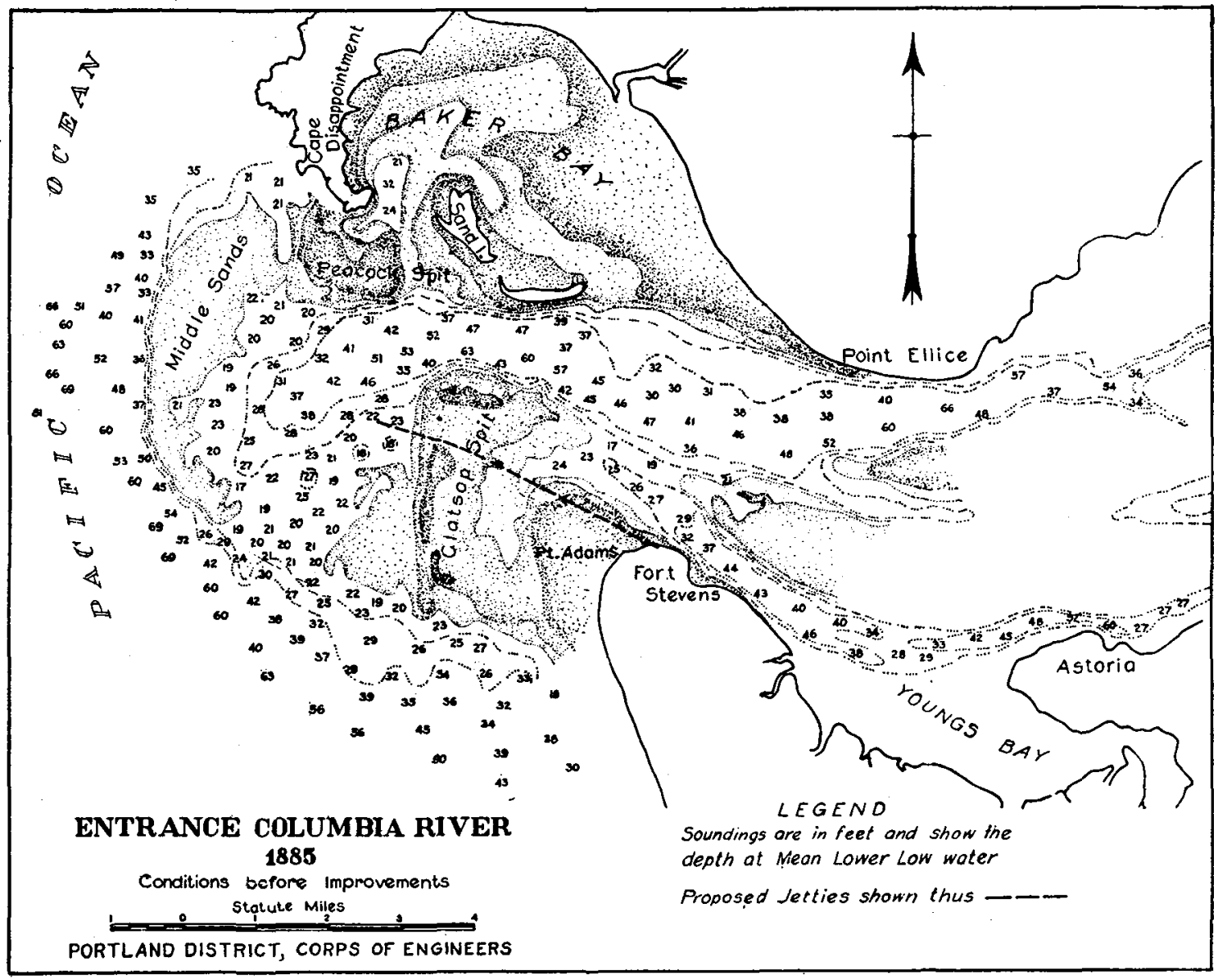

Fig. 3 


\section{HISTORY OF COLUMBIA RIVER JETTIES}

These reports, in general, agree that sand of the beach south of the entrance: combined with sand brought in from the floor of the ocean, steadily moved to the north past Point Adams in a prolongation of the beach itself. Under the dispersing effects of currents and wave action, this sand had been scattered to form Clatsop Spit. Irrespective of the source, continuous accretions to the north side of clatsop Spit steadily encroached upon the channel and pushed it to the north, accompanled by a wearing away of the opposite bank and deepening of the channel. The point of greatest erosion was at the extremity of the spit's crest, and here was the river gorge, the deepest and narrowest section of the entrance channel.

Conditions at the entrance in 1895, when the original south jetty was completed, is shown in Fig. 4. Deterioration of the channel by 1902 is shown in Fig. 5. Improvement of the channel by the time the extension of the south jetty was completed in 1913, and when the north jetty was 90 percent completed in 1916 , is shown in Figs. 6 and 7, respectively. The condition of the entrance in 1950 is shown in Fig. 8 .

The set of the main channel ebb tide is to the southwest at all seasons, and the channel to the ocean has consistently remained across the southwest quadrant of the bar; the only exceptions to this rule having been the channel shown by Admiral Vancouver's sketch of 1792, and deteriorating channels that have worked around to a northerly direction. The northerly movement of clatsop Spit and the river gorge, while the channel across the bar remained in the same general 1ocation, increased the length of the main channel until it was much greater than the distance between deep-water curves measured directly across the root of clatsop

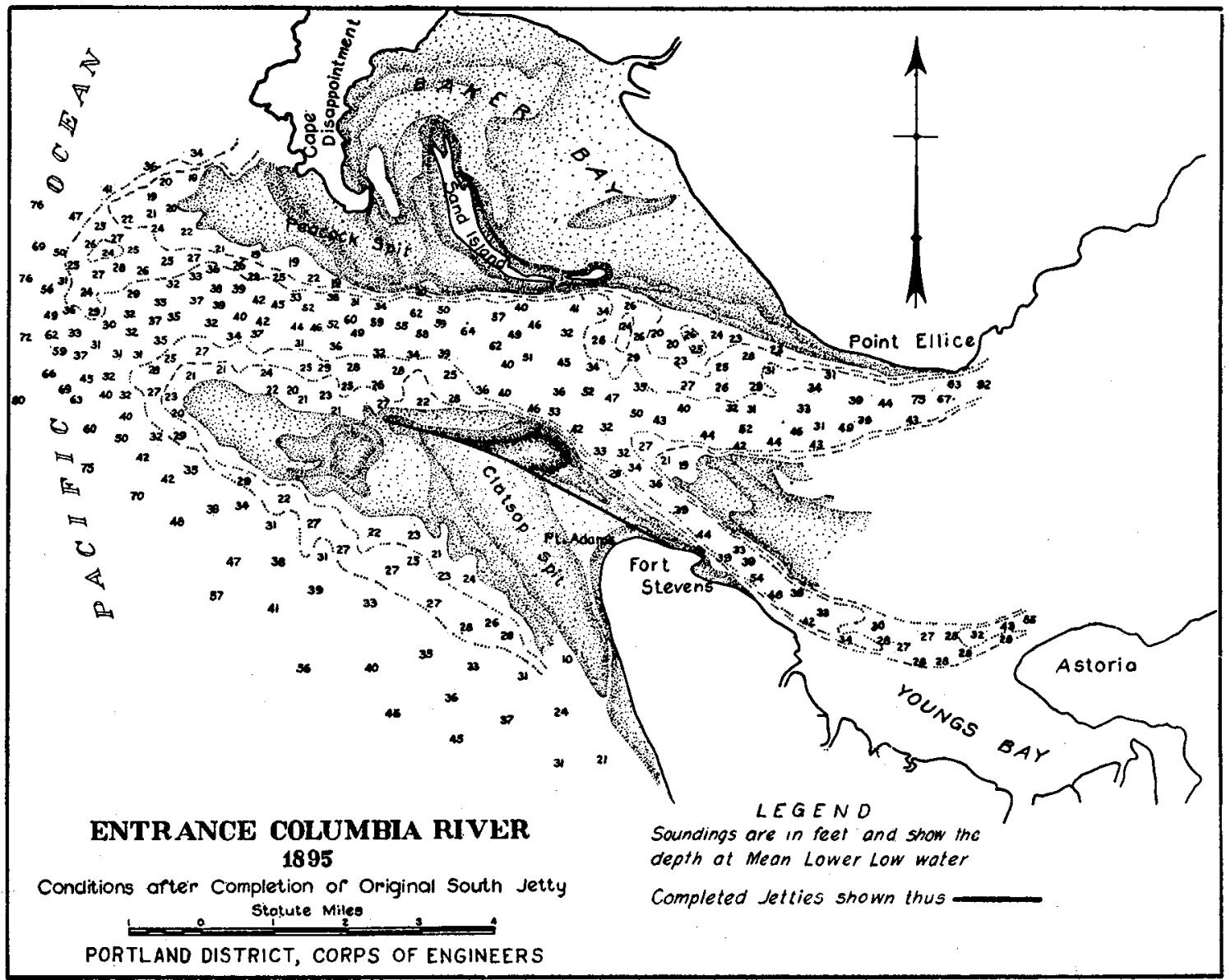

Fig. 4 
Spit, and the shorter route became the easy route for the tidal flow. When the difference became sufficient the tidal flow would cut a swash channel across the spit. Under favorable conditions the swash channel would gradually increase in depth, and the main channel, partially robbed of the tidal flow, would begin to shoal so that there would be two inferior channels. Gradually, the channel across the root of Clatsop Spit would become the main channel, leaving the northern portion of clatsop Spit as a middle ground or island. An examination of the old charts shows that Sand Island, which today separates Baker Bay from the river, probably was cut off from Clatsop Spit between 1792 and 1839 and gradually shifted north and east to its present location.

The many changes in the shoals at the river entrance added greatly to the hazards of navigation. In order to improve the channel, congress, by the River and Harbor Act of August 2, 1882, authorized a board of engineers "to examine in detail the mouth of the Columbia River, Oregon, and report such plan, with estimates, for its permanent improvement as they approve." The board submitted its report on October 13, 1882, and 1t was printed in Senate Executive Document No. 13, 47 th Congress, 2nd session.

The board of engineers used the river section between Chinook Point and Point Adams to determine the area of a section which would maintain itself, decided it was impracticable to diminish the area between Cape Disappointment and Point Adams by a detached structure on the bar, and recommended "....the construction, at as early a day as possible, of a jetty, slightly convex to the north, extending.from the shore near Fort Stevens (on Point Adams) in a northwesterly direction towards



F1g. 5 
a point about 3 miles south of Cape Disappointment, this jetty to stop short of that point or be prolonged beyond it, as experience may indicate to be necessary." The board also mentioned the possibility of a jetty on Peacock Spit. In view of the exposed location and the difficulty in maintaining any structure the board proposed the jetty be brought to the height of low tide, or higher, if experience showed necessity therefor.

\section{HISTORY OF THE SOUTH JETTY}

Construction of the south jetty was begun in 1885 but proceeded so slowly that it did not affect the condition of the bar channel until 1889 . Rapid construction commenced in 1889 and its effect on the bar was immediately noticeable. In 1893 a board of engineers was convened to consider results attained and to report a plan for final completion. This report, submitted in May 1893 , recommended construction of four groins on the north side of the jetty (shown in Fig. 5), and that the jetty at the shore end should be carried to $12 \mathrm{ft}$. above low water, should slope to plus $10 \mathrm{ft}$. at $1-1 / 8 \mathrm{miles}$ from shore, whence it should slope to plus $4 \mathrm{ft}$. at its outer end, the total length to be $4-1 / 2$ miles. All of these recommendations were carried out and the jetty was completed in 1895 . The jetty was of rubble-mound type, built from trestle work.

The changes in the channel induced by construction of the jetty were large and important. The channel depth, which was $20 \mathrm{ft}$. In 1889, increased to $31 \mathrm{ft}$. In 1895, remalned at $30 \mathrm{ft}$. through 1896 and 1897, then began to decrease. The direction of the channel, which had a bearing west of south in 1885, gradually



Fig. 6 


\section{COASTAL ENGINEERING}

swung around to the north as construction of the jetty proceeded, and by 1895 the channel ran almost due west and was in splendid condition. The swing to the north continued, however, and the depth increased to $22 \mathrm{ft}$. In 1902, when the remalns of the old bar channel pointed nearly due north and there were two new channels of almost equal depth across the western sector of the bar. It was evident that further improvement of the mouth of the river was necessary.

The River and Harbor Act of March 3, 1899, authorized examination and survey of the mouth of the river "with a view to obtaining a channel 40 feet deep at lowest water, and a report as to the desirability of such improvement." The report is contained in House Document No. 94, 56th Congress, 1st session. This project was referred to a board of englneers who, on January 24, 1903, submitted a report that provided for extending the existing south jetty due west for a distance of 2-1/2 miles, construction of a north jetty from Cape Disappointment to a point 2 miles north of the outer end of the 2-1/2-mile extension of the south jetty, and dredging.

The extension of the south jetty was started in 1903 and completed in 1913. The jetty was constructed of rubble stone, and, because the exposure was so great and the incessant wave action prevented repair operations by floating plant, it was necessary to delay maintenance until the amount of work required would justify the cost of the necessary trestle and plant. No maintenance was done on the jetty until the fall of 1931, and by that time the sea had flattened the enrockment to about 102-water level and spread out the stone so that the width of the outer $2-3 / 4$ miles was about $200 \mathrm{ft}$. at low-water level. Under three contracts, 2,200,000

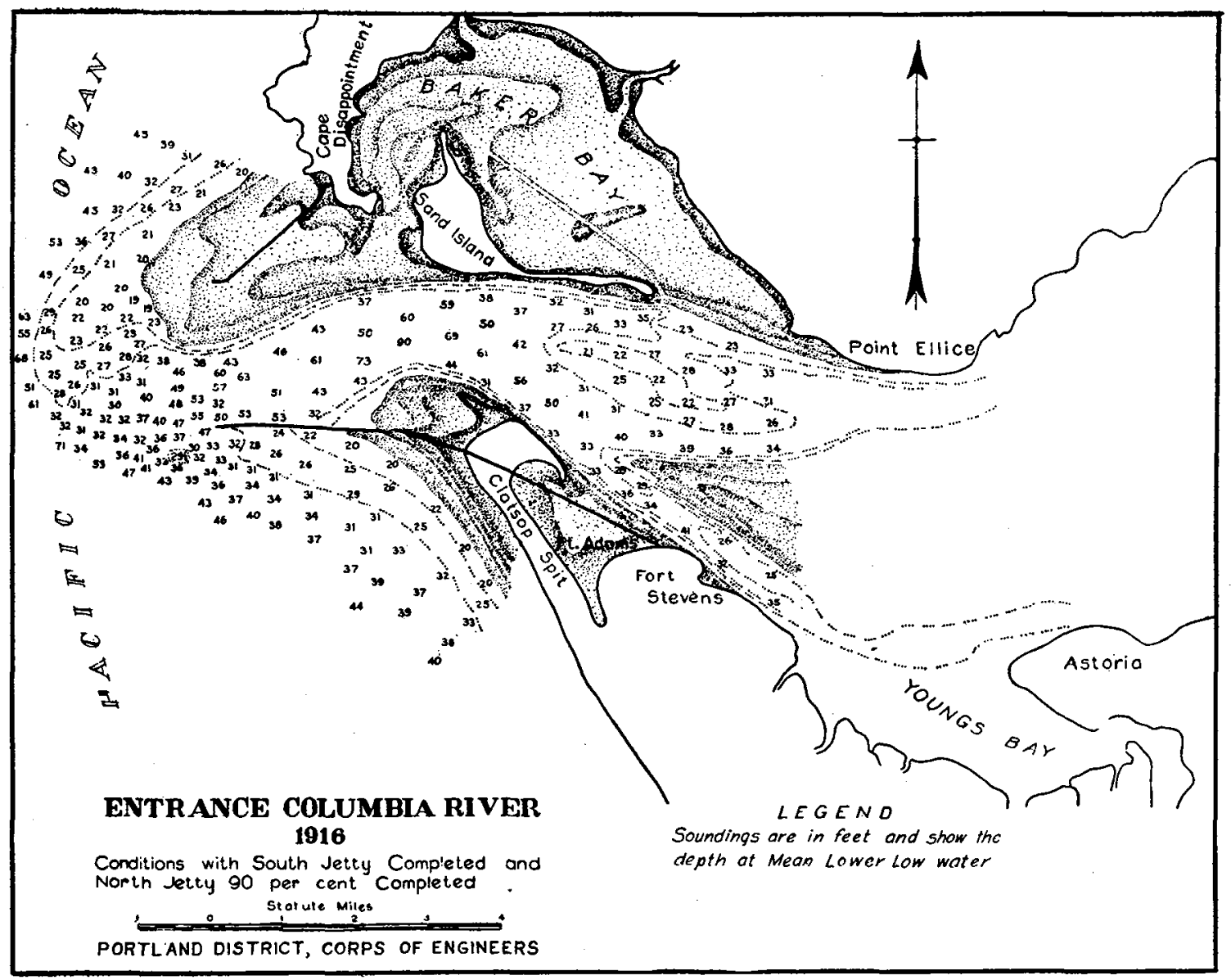

F1g. 7 


\section{HISTORY OF COLUMBIA RIVER JETTIES}

tons of stone were placed in the superstructure, which was carried out to within approximately $3,300 \mathrm{ft}$. of the outer end of the jetty as completed in 1913 . This was believed to be the limit of the superstructure required. The reconstruction of the south jetty was completed in 1936, but the action of waves across the end face of the new work started piecemeal disintegration of the outer end. During a normal winter season the superstructure would ravel back $300 \mathrm{ft}$. or more. The outer end was impregnated with 12,737 tons of hot mixture of asphaltic mastic (85 percent sand and 15 percent asphalt) in an attempt to prevent raveling. While computations and later observations indicate that the asphaltic mix completely fllled the voids to about low-water level ( $26 \mathrm{ft.}$ ), it did not prevent breakdown of the end, and raveling still continued. A solid concrete terminal was then constructed above low-water level and has proven effective. The concrete terminal is about 3,900 ft. shoreward from the end of the original jetty as conpleted in 1913 .

The south jetty as now constructed is a massive structure (see Figs. 9, 10, and 11). The top width varies from $45 \mathrm{ft}$. to $70 \mathrm{ft}$., with an elevation of $26 \mathrm{ft}$. above mean lower low water. The sea slope is approximately 1 on $1-1 / 2$ consisting of stone welghing up to about 25 tons, with 45 percent of entire enrockment having an average weight of 10 tons to the piece. The base width of the outer portion is. approximately $350 \mathrm{ft}$. and the total height from bottom ranges up to $76 \mathrm{ft}$. The outer 3,900 ft. have been beaten down to 10 or more feet below low water and rebuilding is not believed to be necessary. This outer section, in depth of $70 \mathrm{ft}$., serves as a protective apron.

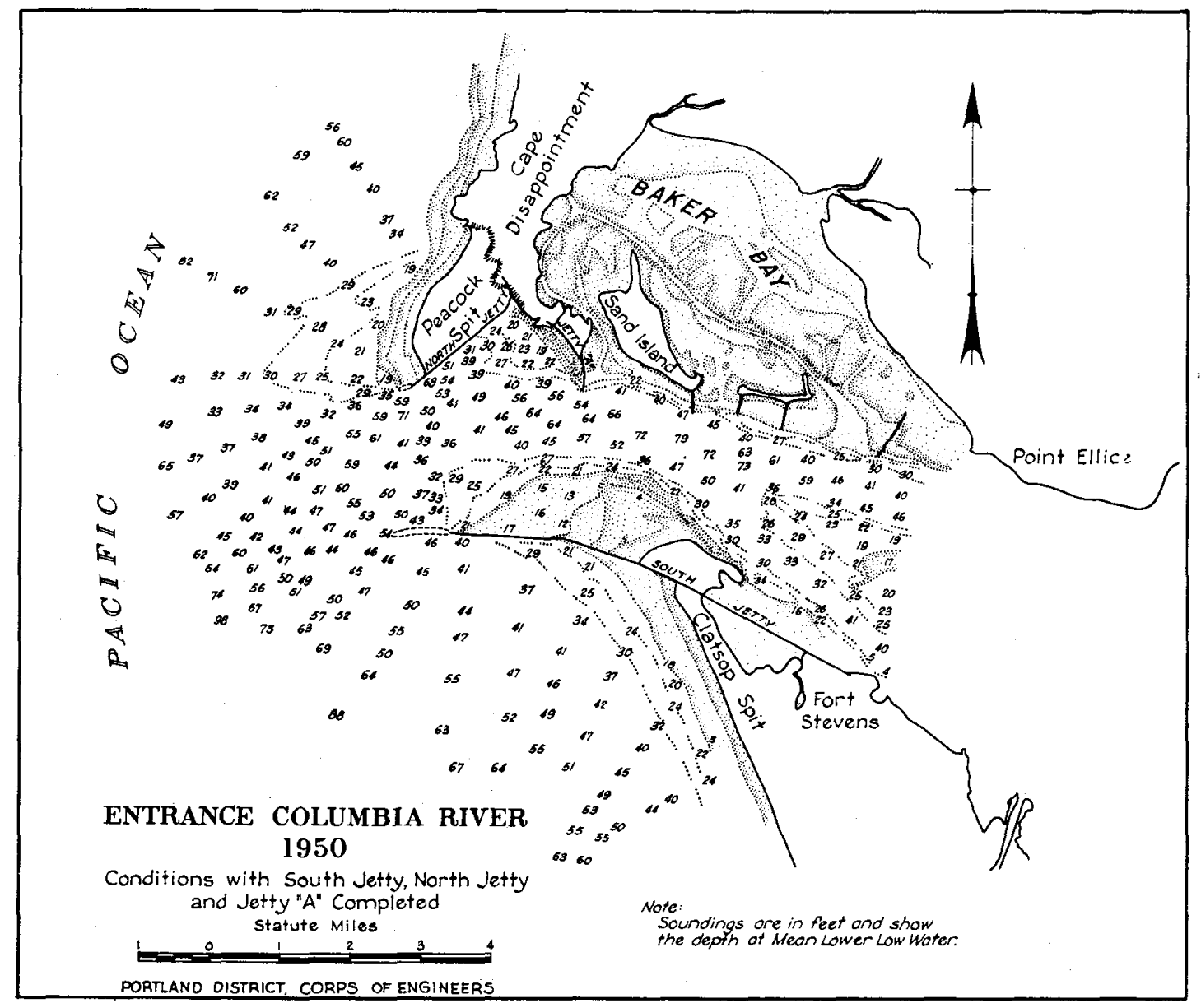

F1g. 8 


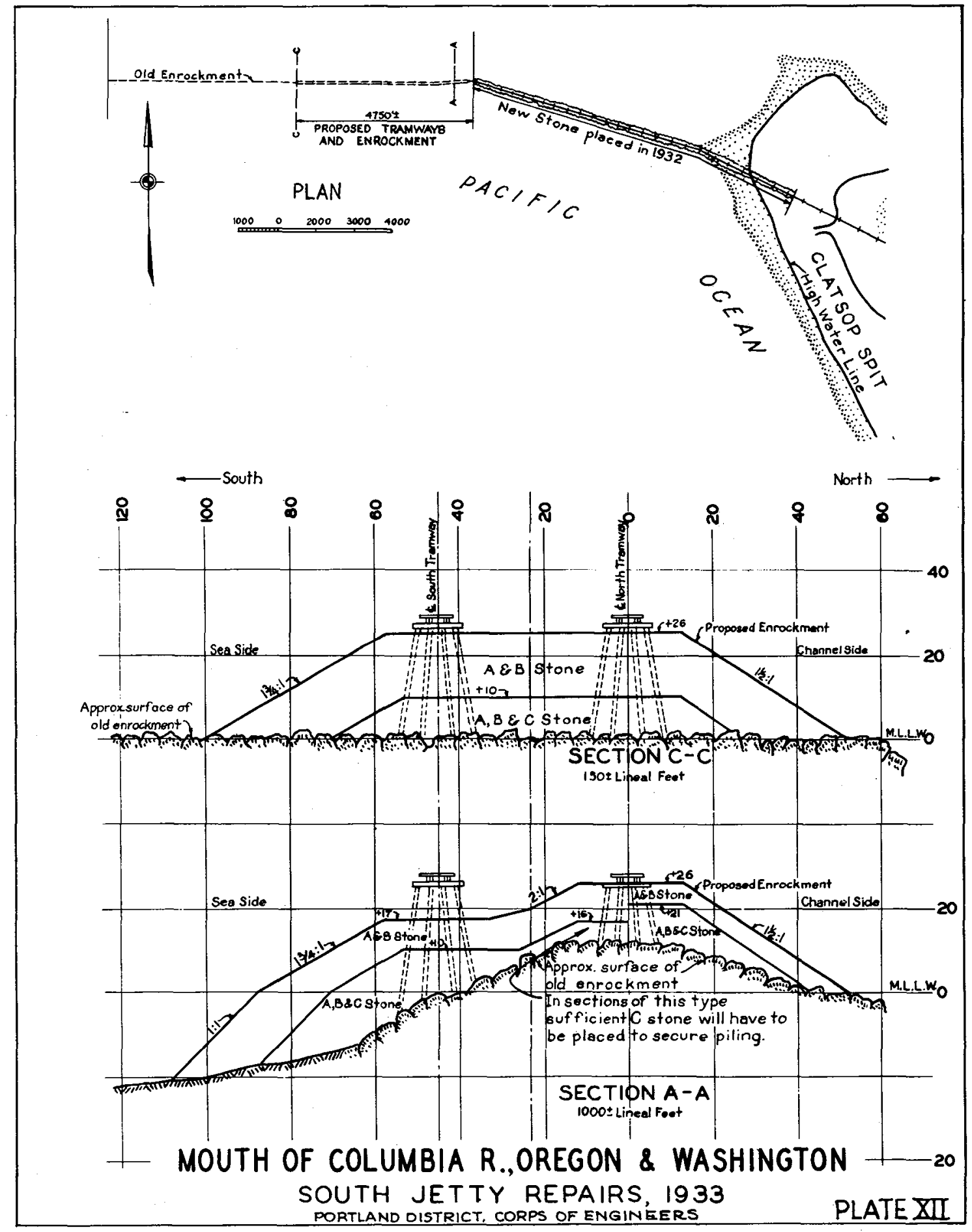

Fig. 9 



MOUTH OF COLUMBIA RIVER,

OREGON AND WASHINGTON

SOUTH JETTY TERMINAL

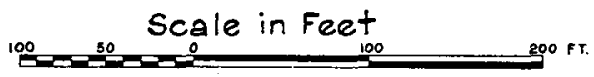

PORTLAND DISTRICT, CORPS OF ENGINEERS

Fig. 10

\section{HISTORY OF THE NORTH JETTY}

As construction of the extension of the south jetty progressed it became apparent that a north jetty would be necessary to stabilize the entrance and secure and maintain a channel $40 \mathrm{ft}$. deep. Durling 1912-1913, while the extension of the south jetty was still. in progress, preparations were made for construction of the north jetty. Actual construction started in september 1913 and was pushed to completion in 1917, by which time the controlling depth on the bar had increased to $37 \mathrm{ft}$. The root of this jetty is on the west side of Cape Disappointment at the west end of a swale which cuts through the cape from Baker Bay to the ocean front, about 3,000 ft. from the southern end of the cape. The jetty was constructed $25 \mathrm{ft}$. wide on top with side slopes about $I$ on $1-1 / 2$, and elevation of the top from 28 to $32 \mathrm{ft}$. above mean lower low water. The jetty extended southwestward for about 2 miles, to a point 2 miles north of the south jetty, then turned westward for about $1,700 \mathrm{ft}$. Nearly 3 million tons of stone were placed in the stmucture.

The outer portion of the north jetty was subject to wave action across the end and by 1930 was flattened to low water. The part of the jetty extending southwestward from the shore for 2 miles, however, had been backed up by a natural sand f111 on the northerly side and strongly resisted destruction by wave action. Some damage resulted from undercutting along the southeasterly or river face, and in 19381939 the north jetty was rehabilitated and a concrete terminal block was placed at the outer end. The outer portion extending westward from the turn, which had been flattened to low-water level, was not reconstructed. This outer section serves as an apron on the sea slope. 


\section{COASTAL ENGINEERING}

SHORE CHANGES SOUTH OF THE SOUTH JETTY

Between 1880 and 1883 a swash channel was cut across the root of clatsop SpIt about I mile northwestward of Point Adams. When construction of the south jetty blocked wave action across clatsop spit, sand accumulated on the south side of the jetty, ralsing the elevation of that portion of clatsop Spit between the ocean and the swash channel and holding the channel against Point Adams beach. $A$ new beach was thus established between the south fetty and the southern end of the swash channel which was gradually filled with the encroaching sand. By 1899 the southern out-
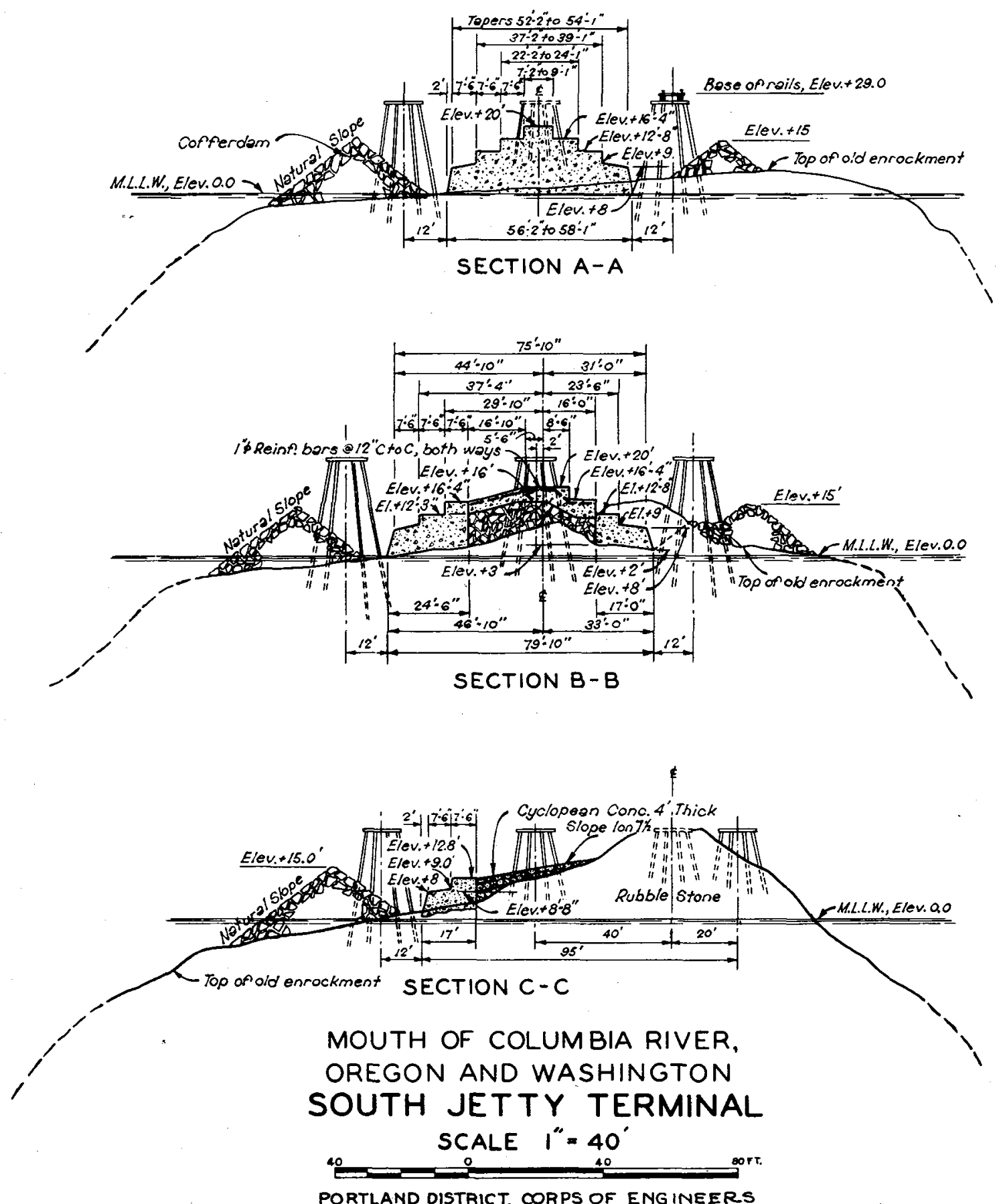

PORTLAND DISTRICT, CORPS OF ENGINEERS

Fig. 11 


\section{HISTORY OF COLUMBIA RIVER JETTIES}

let had been closed of $f$ and the northern portion of the swash channel became a lagoon separating the new beach from the beach along the ocean side of Point Adams. Fig. 3 (1885) shows the swash channel before the south jetty was built across it. Fig. 4 (1895) shows the sand accumulated on the middle ground and the southern portion of the channel narrowed to near closure. Fig. 5 (1902) shows the remaining portion of the swash channel as a lagoon in the triangle formed by the old beach

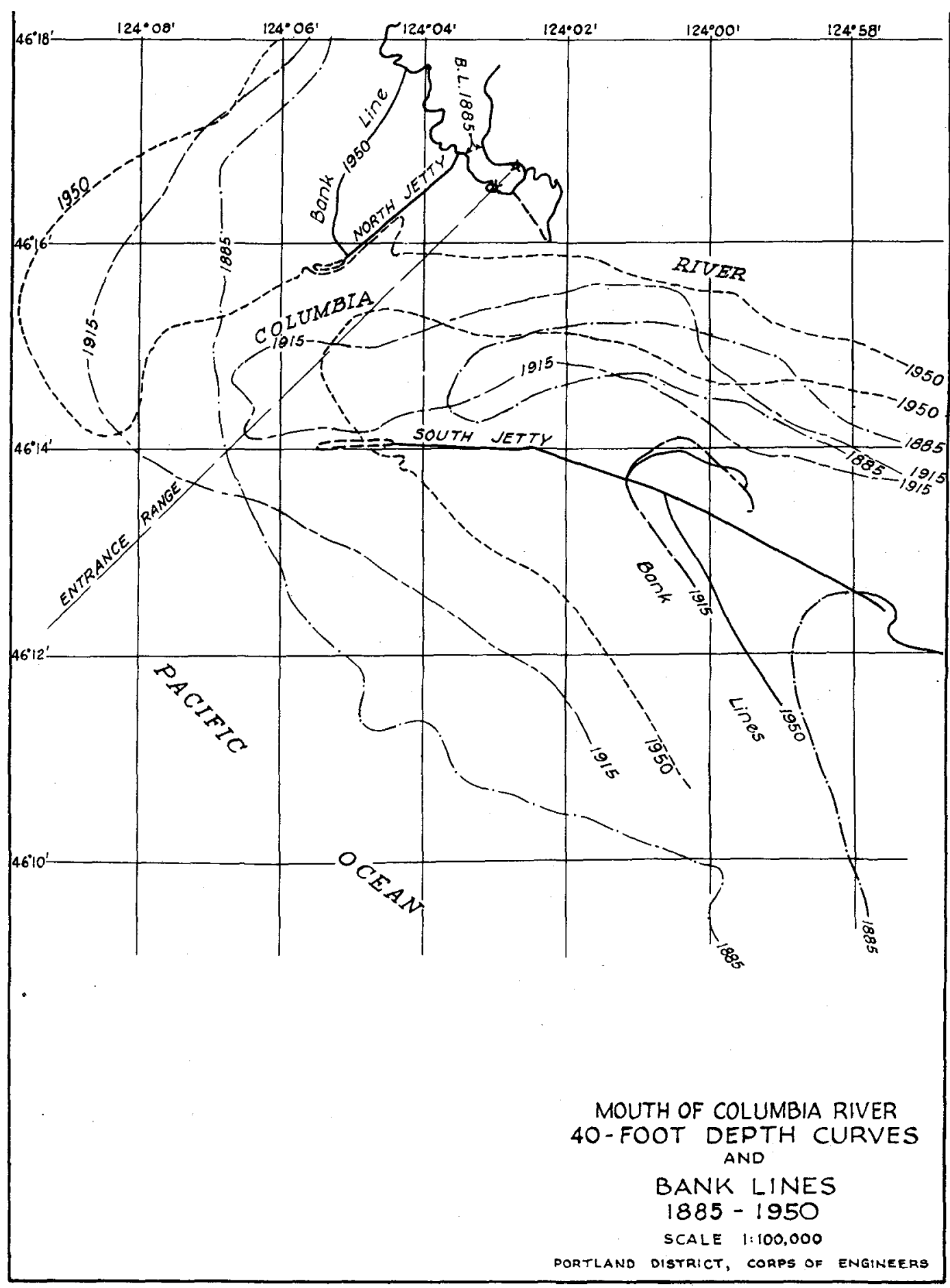




\section{COASTAL ENGINEERING}

along Point Adams on the east, the jetty on the northeast, and the landward side of the new beach on the southwest. As the new beach of clatsop Spit continued to increase in height and advance seaward along the south side of the jetty, it created a new south point to the entrance, which, by 1900 , was about 3 miles northwest of Point Adams. This was the outer-most position reached by the beach and since then it has receded about $1 / 2$ mile.

The south jetty was built out across the submerged sands of clatsop spit, and a considerable portion of the spit lay on the northerly side between the jetty and the river channel. After 1889, when construction of the jetty was accelerated, the shoals on the river side of the jetty started to erode and, apparently, a considerable portion of the eroded sand was redeposited on the outer bar so that clatsop Spit continued along the south side of the jetty and extended beyond, forming the crest of the ocean bar (see Figs. 3 and 4). As the accretion to clatsop spit had forced the river channel north before construction of the jetty, accretion to the crest of the bar now forced the channel crossing to the north until, in 1902, the channel headed nearly due north. The channel lost depth and definition as it was forced northward.

Before construction of the south jetty the sand of clatsop spit, combined with sand from other sources, was washed into the ocean by tidal currents and, transported shoreward by ocean waves, eventually landed on the beach. Thus the south beach was continually being fed by sand washed into the ocean from the mouth of the river. The south jetty disrupted this cycle of sand movement, and the 40-ft. depth contour off the shore began to move shoreward over an area extending about 5 miles south of the outer end of the fetty. At the southern end of this area the $40-f t$. contour remained in approximately the same location but, at the midpoint, the contour receded shoreward over 1 mile between 1885 and 1900 and has continued to recede so that by 1945 it had receded nearly 2-1/2 miles. At the northern end of the area the 40-ft. depth contour receded 1.7 miles between 1885 and 1950 (see Fig. 9). (Attempts to feed beaches artificially by dumping dredged material off the beach in depths less than $40 \mathrm{ft}$. have not proved successful.)

As the new beach line of clatsop spit was raised above high water, the sand surface was exposed to erosion by wind. Following the initial accumulation and advance of the shore line seaward along the south jetty, as previously alluded to, recession of the shore line has proceeded steadily up to the present time. Wind transportation is an important factor in eroding the beach, but sand fences and grass plantings are now successfully used to limit, to some extent, the amount of sand transported by winds and the distance the sand is transported. There appears to be a southerly littoral drift of sand inside the line of breakers during the summer months and some sand has accumulated on the southern end of the beach in front of the clty of seaside since the jetty was constructed. The recession of the beach has been mostly limited to an area extending about 3 miles south of the jetty. The total recession, normal to the beach line, has been about 2,000 ft., fust south of the jetty, and about 1,000 ft., 2 miles south (see Fig. 9).

\section{SHORE CHANGES NORTH OF THE NORTH JETTY}

The north jetty was constructed across Peacock Spit where depths ranged from 9 to $16 \mathrm{ft}$. and the low-water contour was along the base of Cape Disappointment. Depths of the water between the jetty and the south side of North Head ranged from 9 to $18 \mathrm{ft}$. As the jetty was built out from shore, the portion of the spit north of the jetty began to rise in elevation and, by 1917 , when the jetty was completed. the spit was above low-water elevation in places along the jetty. The area between the jetty and North Head continued to rise in elevation and by 1930 the entire area from near the outer end of the jetty to North Head was filled to heights of 12 to $17 \mathrm{ft}$. above low water. About 48 mililon cubic yards of sand have been deposited in that area since construction of the north jetty was started in 1913 . This trapping of sand has apparently resulted in starving the north shore line of the river all the way to the east end of Sand Island, with resultant erosion.

\section{CHANGES IN THE ENTRANCE SINCE CONSTRUCTION OF THE JETTIES}

Inspection of maps of the mouth of Columbia River shows that, in general, changes over short periods of time are of the same pattern as changes over longer periods, although the rate of change may be different. After completion of the 


\section{HISTORY OF COLUMBIA RIVER JETTIES}

jetties in 1917, depths on the southwest sector of the outer bar increased and by 1921 there was a least depth of $43 \mathrm{ft}$. for a width of 4,500 ft. and of $40 \mathrm{ft}$. for a width of over $6,000 \mathrm{ft}$. Since that time a channel in excess of project dimensions has been maintained without dredging.

Inside the outer bar, between the jetties, the deep water was on the south side, in 1917, with depths in excess of $50 \mathrm{ft}$. Built up by continuous accret1ons, clatsop spit grew to the north and west. Near the outer end of the south jetty the 40-ft. depth contour advanced 5,000 ft. westward and 4,000 ft. northward, and opposite the "knuckle," about 2-1/2 miles in from the outer end of the south jetty, the 40-ft. contour advanced 2,500 ft. northward between 1917 and 1932 . Th1s steady encruachment upon the deep water pushed the channel north, accompanied by a corresponding cutting away of the north bank. The 40-ft. depth contour along the north side of the channel receded northward 1,500 ft. opposite the south end of Cape Disappointment and about 3,700 ft. opposite the outer end of the north jetty. During this period of time the volume of sand in that portion of clatsop Spit north of the south jetty was greatly increased. The source of the sands which made the increase of Clatsop Spit is not easily determined, but during most of the time between 1917 and 1932 the south jetty was in a condition which permitted sand to pass across it, and 1 is is assumed that a large part of the sand came from the south. This material was carried across the jetty by the flood tides entering the river.

The deep water in the south side of the channel in 1917 provided an extremely satisfactory inner channel but controlling depths on the outer bar were only 40 to $42 \mathrm{ft}$. and presented a hazard to vessels when there was rough water on the bar. However, the depth on the bar gradually increased and by 1925 there was a channel $1 / 2$ mile wide with depths of 46 to $48 \mathrm{ft}$. In 1925 , Clatsop spit had not encroached upon the inner channel sufficiently to cause undesirable alignment, and shoal depths on the westerly sector of the outside bar protected the channel from westerly waves. The combination of deep water on the outer bar, excellent alignment of the entrance channel, and protection from westerly waves afforded by shoal depths on the western portion of the bar provided the most satisfactory condition ever attained at the mouth of the river. The splendid entrance conditions continued throughout 1925 and 1926 but by 1928 clatsop spit had advanced into the river, and the navigation channel was being forced to the north. The westerly section of the outer bar continued to erode until depths increased from 20 ft. to about $38 \mathrm{ft}$. at low water so that now (1950) they are only 7 to $8 \mathrm{ft}$. less than depths in the ship channel across the southwesterly sector of the bar.

As Clatsop Spit advanced into the channel the portion of Peacock Spit lying south of the north jetty deepened and the low-water line receded back to near the base of the cliffs of Cape Disappointment. This permitted tidal currents to develop along the south side of the north jetty, and a deep trench was cut along the outer portion of the jetty.

It is very desirable to secure again the channel conditions that existed in 1925 and 1926 and while this may take a long time, it appears that it may be accomplished by the natural scouring of the southerly bank of the channel upstream, the construction of a stabilizing jetty between the north jetty and jetty "A", supplemented by dredging.

During the period from 1932 to 1938 the south jetty was repaired and improved. To prevent further shifting of the channel to the north with resulting erosion of Sand Island and Peacock Spit, four permeable dikes were constructed out from the south side of Sand Island, and Jetty "A" was built southward from Cape Disappointment. By 1938 these structures had stabilized the north side of the channel east of jetty "A". (See Fig. 8 for location of these structures.)

The 40-ft. depth contour along the north side of the channel remained in approximately the same location except west of jetty "A", where it receded to the north a distance ranging from zero at spur jetty "A" to about 3,000 ft. near the outer end of the north jetty.

The volume of material above the 40-ft. depth, In that portion of clatsop Spit lying north of the south jetty and west of the north and south line $10,000 \mathrm{ft}$. east of Cape Disappointment lighthouse, increased by only 1,200,000 cubic yards 


\section{COASTAL ENGINEERING}

during the six-year period, but the sands shifted in location and, along its west side and the west half of its north side, the spit continued to advance into the channel, which caused the north side of the channel to recede as previously described. The encroachment upon the channel from the south also caused additional scouring off the top of Peacock Spit, which permitted an increased flow of the $\mathrm{ebb}$ tide across to the north jetty with a resulting current along the jetty, and considerable scouring occurred in the deep channel along the outer end of the jetty and extended in a projection of the jetty alignment. Spur jetty "A" caused erosion of the south side of the channel as planned, and the adjacent reach of the channel has been practically stabilized since 1941.

Clatsop spit continued to advance into the channel at its northwest extremity but the rate of advance gradually lessened and since 1947 the bulge to the northwest has remained in approximately the same location. Greater than project dimensions have been maintained round clatsop spit by the tidal and river currents, but the alignment of the channel is objectionable. Starting in 1939, material was dredged from the northwest portion of clatsop spit to better the ship channel alignment.

In 1885 the outer face of the bar was approximately 3 miles west of Cape Disappointment. Construction of the jetties forced the bar further into the ocean so that by 1900 the outer face had advanced $1 \mathrm{mile}$, and by 1950 the extreme western position of the sea face of the bar was over 5 miles west of Cape Disappointment. As the outer perimeter of the bar advances into the ocean the original depth of water increases and the rate of advance becomes less. Fig. 12 shows the advance seaward of the 40-ft. depth contour since 1885 . 